\title{
Risk of Myrothecium Roridum Leaf Spot in Local Cucurbitaceous Crops of Pakistan
}

\author{
Bilal Yousaf ${ }^{1}$, Asad-ur-Rahman*2, Muhammad Sajjad ${ }^{2}$, Saeed Ahmad ${ }^{2}$, Arshad Hussain², Manzoor Hussain² and \\ Sunny Jabbar ${ }^{1}$ \\ ${ }^{1}$ Department of Plant Pathology, University of Agriculture Faisalabad, Pakistan
}

${ }^{2}$ Department Plant Pathology section, Regional Agriculture Research Institute, Pakistan

Submission: May 29, 2018; Published: July 18, 2018

"Corresponding author: Asad-ur-Rahman Ch, Plant Pathology section, Regional Agriculture Research Institute, Bahawalpur, Pakistan, Tel: +923053987681; Email: sherani639@gmail.com

\begin{abstract}
Myrothecium roridum is a disastrous pathogen of grain, fruit and vegetable crops including cucurbits. It has been reported to parasitize a number of crops in Pakistan. To find out the cucurbitaceous host range of the fungus, pathogenicity was done on eight cucurbit species in controlled conditions. The results reveal that M. charantia, C. melo, C. sativus L. and C. lanatus are least resistant hosts of this disease with D.I. of $49.84,48.21,45.25$ and $44.86 \%$ respectively. On the other hand, three vegetables species viz. L. aegyptaca (17.61\%), L. siceraria (22.72\%) and C. pepo (23.57\%) showed least resistance. One species i.e. P. fistulosus (38.13\%) showed moderately susceptible response. All the results were evaluated by using M.STAT software under completely randomized design.
\end{abstract}

Keywords: Myrothecium roridum; Cucurbits; Host range; Water melon; Bitter gourd; Sponge gourd; Muskmelon; Cucumber

\section{Introduction}

Apart from agronomic crops, vegetables are a significant source of income for our small land holders as well as for tunnel farmers. There are more than 36 vegetables grown commercially in Pakistan including cucurbits as major food crops of the country [1]. According to Agricultural Statistics of Pakistan [2] area under vegetable cultivation and total production was 265.7thousand ha and 3132.7thousand tons respectively. However, heavy crop losses $(20-30 \%$ in horticulture crops and $10-15 \%$ in agronomic crops) due to disease attacks are hampering the profitability of the national agricultural industry [3]. The real yield potential of these vegetables is far from being probed out and production in the country is not up to the mark when compared with world, vegetable production.

A number of viruses, bacteria, fungi and other annoyances attack these plants at various phases of their development [4] thus reduce the yield and lead to massive losses for human beings [5]. Among them pathogenic fungi are ubiquitous in environment and are more common [6]. They cause upto $12 \%$ preharvest losses of crops in developing countries [7]. Cucurbits are vulnerable to numerous fungal diseases like downy mildew, anthracnose, scab or gummosis, gummy stem blight, charcoal rot, damping off, powdery mildew, Alternaria leaf spot and Myrothecium leaf spot or blight.
Myrothecium species are the chief hazards to crops as well as to cucurbits. The genus Myrothecium is acknowledged to consist of several species, mostly saprophytic [8] and survive in this environment on dead and decaying plant tissue [9-11]. The concept and classification of species within this genus is not clear and still needs revision. Among these species only M. roridum Tode is considered as an expressive plant pathogen. However, M. verrucaria Ditmar is also regarded as a weak phytopathogen [12].

This pathogen causes about 30\% yield losses of soybean in India [13]. Symptomology of infection suggests that it has dark-brown rings or bulky uneven spots on most of host leaves. However zonal development of the abrasions is also noticed. Small sclerotium like marks can also be observed on the façade of the abrasions under humid environment [14]. High relative humidity for a long period helps M. roridum to perpetuate and the disease may occur in epidemic form [15].

It has been found associated with cucurbit species grown in Pakistan [16] like bottle gourd [17], bitter gourd [18], Indian gourd [18], red gourd and sponge gourd. Specifically it has become an emerging threat for bitter gourd production in the country. Sultana and [19] also isolated M. roridum and M. verrucaria from bitter gourd seeds belonging to different regions 
of the country. Specifically, it has become an emerging threat for bitter gourd crop in Pakistan. A research was planned to find out which of 8 cucurbits grown in Pakistan on commercial scale can be victimized by this hostile pathogen.

\section{Materials and Methods}

\section{Raising of Cucurbit plants}

One locally cultivated variety of each of 8 vegetables was obtained from Vegetable Research Institute, AARI Faisalabad. All these plants were grown in plastic pots containing sterilized soil and pots were placed in screen house of Plant Pathology Research Field at University of Agriculture, Faisalabad (Table 1)

Table 1: List of Cucurbit species and varieties used for screening against M. roridum.

\begin{tabular}{|c|c|c|}
\hline Cucurbit Vegetables & Botanical Names & Variety/ Cultivar \\
\hline Cucumber & Cucumis sativus $L$. & Local Sialkot \\
\hline Tinda gourd & $\begin{array}{c}\text { Praecitrullus } \\
\text { fistulosus }\end{array}$ & Tinda DilPazeer \\
\hline Muskmelon & Cucumis melo & T-96 \\
\hline Sponge gourd & Luffa aegyptaca & Faisalabad round \\
\hline Water melon & Citrullus lanatus & Sugar baby \\
\hline Bitter gourd & Momordica charantia & Black king \\
\hline Pumpkin & Cucurbita pepo & Vegetable marrow \\
\hline Long gourd & Lagenariasiceraria & Ghiya tori Local \\
\hline
\end{tabular}

\section{Preparation of Media}

Plating was done on Potato Dextrose Agar (PDA) following the composition described by MacFaddin [20]. All the ingredients were mixed in $1000 \mathrm{ml}$ of distilled water. This mixture was then placed of Magnetic stirrer at 200rpm for 30minutes to mix up thoroughly. Digital autoclave was used for the sterilization of media and glassware at 1210C and 15Psi for 15minutes. Glassware was wrapped in newspaper before autoclaving. After cooling down the media was poured into $9 \mathrm{~cm}$ diameter plates at the rate of $20 \mathrm{ml}$ per plate then allowed to solidify and placed in a refrigerator for further use.

\section{Isolation and Purification}

Infected bitter gourd leaf tissues were obtained from vegetable area of Ayub Agricultural Research Institute, Faisalabad. Infected portion of leaves with healthy part were cut in $2-3 \mathrm{~mm}$ diameter and sterilized with $70 \%$ ethanol for one minute [18]. Then washed with mercuric chloride solution and then dipped into distilled water for 2 minutes to remove residues. Plating, isolation and identification of M. roridum was done in laminar flow hood at Plant Nematology Laboratory of Department of Plant Pathology University of Agriculture, Faisalabad.

\section{Pathogenicity of M. roridum in cucurbits}

Pathogenicity was done at two true leaf seedling stage by spray inoculation of $\mathrm{M}$. roridum conidial suspension at the rate of 106 conidia per $\mathrm{ml}$ of distilled water. Heamocytometer was used for the counting of conidia. Pots were placed in relative humidity chamber and covered with polythene bags for 24 hours to ensure maximum humidity [19] required for penetration of fungus. Completely randomized design with three replications was applied. Separate control (3 replications) was kept for each species. Plants were examined on daily basis and data for disease incidence were recorded after 7 days by using 0 to 4 rating scale (Table 2) [21].

Formula used for disease severity: Disease index $=\frac{\text { sum of all numerical ratings }}{\text { Number of all leaves assesed }} \times \frac{100}{4}$

Table 2: Disease rating scale used for disease severity of $M$. roridum on cucurbit leaves [21].

\begin{tabular}{|c|c|c|}
\hline Ratings & Symptoms & Result \\
\hline 0 & No symptoms & Immune \\
\hline 1 & $1-25 \%$ leaf area infected & Moderately resistant \\
\hline 2 & $26-50 \%$ infection & Moderately Susceptible \\
\hline 3 & $51-75 \%$ infected tissue & Susceptible \\
\hline 4 & $76-100 \%$ leaf area infected & Highly susceptible \\
\hline
\end{tabular}

\section{Results and Discussions}

In this study 8 locally grown cucurbit crops in Pakistan, were tested for the pathogenicity response to an ascomycete fungus M. roridum. All the vegetables under experiment showed susceptible response. This fungus shows ubiquitous nature as it has previously shown some 200 hosts in the world and a number of its hosts present in the country have been manipulated. In the present experiments maximum disease incidence was shown by variety/ cultivar of each of M. charantia (Black King), C. melo (T-96), C. sativus L (Local Sialkot) and C. lanatus (Sugar baby) as $49.84,48.21,45.25$ and $44.86 \%$ respectively. Other three vegetable species viz. L. aegyptaca, L. siceraria and C. pepo showed least susceptibility as $17.61,22.72$ and $23.57 \%$ respectively while one species i.e. P. fistulosus was moderately susceptible to the attack of fungus with $38.13 \%$ disease incidence (Figure 1\&2).

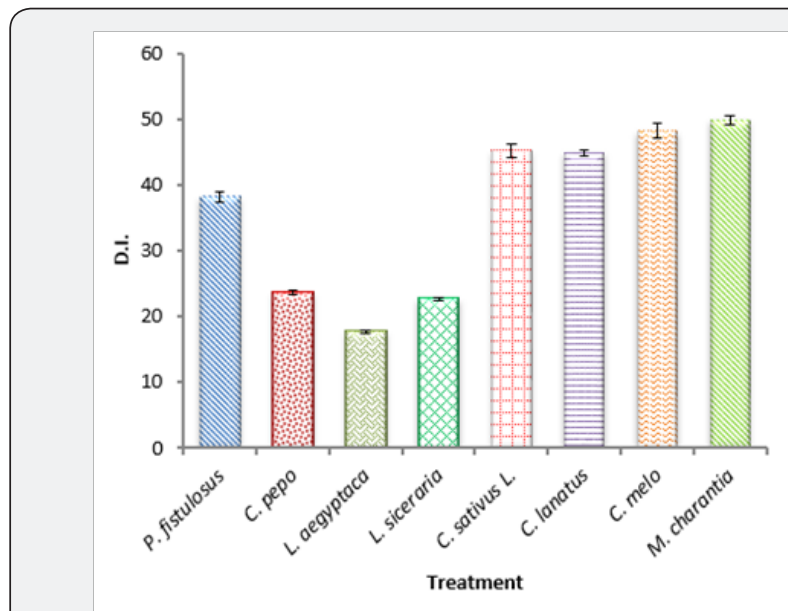

Figure 1: Susceptibility response of Cucurbits for M. roridum. 


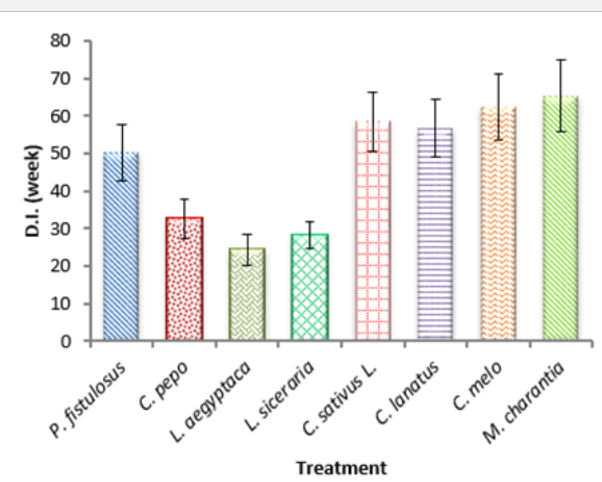

Figure 2: Susceptibility response of Cucurbits for M. roridum in relation to weeks of infection.

All the statistical trials were performed by using statistical software SAS/STAT [22]. Means were separated using Fisher's protected least significant difference (LSD procedure). Data for in-vitro evaluation of chemicals was subjected to statistical analysis under complete randomized design with M.STAT software for determining the significance and non-significance of chemicals [23] (Table 3-6).

Table 3: Means of disease severity of M. roridum on different cucurbit species.Means sharing similar letters are statistically non-significant $(P>0.05)$.

\begin{tabular}{|c|c|}
\hline Treatment & Mean \pm SE \\
\hline P. fistulosus & $38.13 \pm 0.72 \mathrm{C}$ \\
\hline C. pepo & $23.58 \pm 0.37 \mathrm{D}$ \\
\hline L. aegyptaca & $17.61 \pm 0.28 \mathrm{E}$ \\
\hline L. siceraria & $22.72 \pm 0.22 \mathrm{D}$ \\
\hline C. sativus L. & $45.25 \pm 1.04 \mathrm{~B}$ \\
\hline C. lanatus & $44.86 \pm 0.53 \mathrm{~B}$ \\
\hline C. melo & $48.21 \pm 1.18 \mathrm{~A}$ \\
\hline M. charantia & $49.84 \pm 0.68 \mathrm{~A}$ \\
\hline
\end{tabular}

Table 4: Analysis of Variance Table for D.I. shown by different cucurbits. NS = Non-significant $(P>0.05) ;{ }^{*}=$ Significant $(P<0.05) ;{ }^{* *}=$ Highly significant $(P<0.01)$.

\begin{tabular}{|c|c|c|c|c|}
\hline $\begin{array}{c}\text { Source of } \\
\text { Variation }\end{array}$ & $\begin{array}{c}\text { Degrees of } \\
\text { Freedom }\end{array}$ & $\begin{array}{c}\text { Sum of } \\
\text { Squares }\end{array}$ & $\begin{array}{c}\text { Mean } \\
\text { Squares }\end{array}$ & F-Value \\
\hline Treatment & 7 & 3532.76 & 504.68 & $335.0^{* *}$ \\
\hline Error & 16 & 24.04 & 1.502 & \\
\hline Total & 23 & 3556.8 & & \\
\hline
\end{tabular}

Table 5: Analysis of Variance Table for D.I. in relation to number of weeks of infection. NS = Non-significant $(P>0.05) ;{ }^{*}=$ Significant $(P<0.05) ;{ }^{* *}=$ Highly significant $(P<0.01)$.

\begin{tabular}{|c|c|c|c|c|}
\hline $\begin{array}{c}\text { Source of } \\
\text { Variation }\end{array}$ & $\begin{array}{c}\text { Degrees of } \\
\text { Freedom }\end{array}$ & $\begin{array}{c}\text { Sum of } \\
\text { Squares }\end{array}$ & $\begin{array}{c}\text { Mean } \\
\text { Squares }\end{array}$ & F-Value \\
\hline Week & 2 & 2227.14 & 1113.57 & $74.95^{* *}$ \\
\hline Treatment & 7 & 5667.31 & 809.62 & $54.49^{* *}$ \\
\hline Error & 14 & 208 & 14.86 & \\
\hline Total & 23 & 8102.45 & & \\
\hline
\end{tabular}

Table 6: Means disease severity of $M$. roridum in relation to number of weeks of infection. Means sharing similar letters are statistically nonsignificant $(P>0.05)$.

\begin{tabular}{|c|c|}
\hline Week & Mean \pm SE \\
\hline W1 & $35.94 \pm 4.59 \mathrm{C}$ \\
\hline W2 & $46.49 \pm 5.65 \mathrm{~B}$ \\
\hline W3 & $59.49 \pm 7.21 \mathrm{~A}$ \\
\hline
\end{tabular}

Leath \& Kendall [24] observed rot of roots in red clover and alfalfa fields. The fungus M. roridum was first reported to be pathogenic to muskmelons (Cucumis melo) by Mclean \& Sleeth [25]. The fungus then showed its ubiquitous behavior when it was isolated from tomato (Solanum lycopersicum) plant belonging to another family, solanaceae by Khan \& kamal [26] in Pakistan. This fungus contains relatively wide host range including horticultural and field crops such as cotton, potato, tomato, coffee, soybean, cocoa and cucurbits as well as numerous ornamental plants [27,28]. Ali et al.[18] found infected leaves of bitter gourd with small yellow to purplish brown and black, circular to irregular spots at Vegetable Research Area of Ayub Agricultural Research Institute, Faisalabad.

Quezado et al. [17] also found out some unfamiliar hosts of the Myrothecium fungi in Brazil. In their study they isolated M. roridum and M. verrucaria from three vegetable plants (sweet pepper, tomato and cucumber), four ornamental species (Spathiphyllumwallisii, Solidago canadensis, Anthurium andeanum and Diffenbachiaamoena) and a weed belonging to solanaceae family (Nicandra physaloides) and confirmed pathogenicity.

Gaikwad [29] studied the host range of M. roridum. He observed moth (Phaseolus acontifolius Jacq), green gram (Phaseolus mungo L.), cowpea (Vigna radiate Endl), pigeon pea (Cajanuscajan L. Millsp), pea (Pisum sativam L.), okra (Abelmoschus esculantum L. Moench), soybean (Glycine max merr), peanut (Arachishypogaea L.), potato (Solanum tuberosum L.), cotton (Gossyipumhirsutum L.), wheat (Triticum aestivum L.), pearl millet guar (cyamopsistetragonoloba), tomato (Lycopersicum esculantum Mill) and maize (Zea mays L.) as most effective host for the pathogen. Meyer et al. [30] studied the leaf spots disease caused by M. roridum (Tode ex Fr.) on cotton field in Maranhao state of Brazil, triggering yield loss of above $60 \%$. The disease symptoms were lesions with concentric, necrotic rings, with striking structures (sporodochia) described irregularly.

\section{Conclusion}

Bitter gourd, muskmelon, cucumber and water melon are more likely to be infected by disease with D.I. of $49.84,48.21$, 45.25 and $44.86 \%$ respectively while three other vegetables viz. sponge gourd, long gourd and pumpkin showed least resistance with $17.61,22.72$ and $23.57 \%$ disease incidence respectively. Only Tinda gourd $(38.13 \%)$ showed moderate susceptibility. The overall result reveals that all the 8 cucurbits were hosts of M. roridum. 


\section{References}

1. Malik HA, Mansoor S, Iram S, Briddon RW, Zafar Y (2010) Severe disease of melon in North West Frontier Province is associated with simultaneous infection of two RNA viruses. Pak J Bot 42(1): 361-367.

2. Agricultural Statistics of Pakistan (2015) Area and Production of Vegetables. Government of Pakistan Ministry of National Food Security and Research: Economic wing pp 86.

3. Chandel, ansA, KamalRM (1995) Post harvest management in Agriculture, SAARC Bibliographic Database. Agricultural Information Center (SIAC) Dhaka 14-28.

4. Tapwal A, Nisha S, Garg N, Gautam, Kumar R (2011) In vitro antifungal potency of plant extracts against five phytopathogens. Braz Arch Biol Techn 54(6): 1093-1098.

5. Singh G, Gupta S, Sharma N (2014) In vitro screening of selected plant extracts against Alternaria alternata. J Exp Biol Agri Sci 2(3): 344-351.

6. Dellavalle PD, Cabrera A, Larranaga P, Ferreira F, Rizza MD (2011) Antifungal activity of medicinal plant extracts against phytopathogenic fungus Alternaria spp. Chil J Agric Res 71(2): 231-239.

7. Lee SE, Kim JE, Lee HS (2001) Insecticides resistance in increasing interest. Agri. Chem. Biotechnol 44(3): 105-112.

8. Quezado DAM, Henz GP, Paz-Lima ML, Medeiros AR, Miranda BEC, et al. (2010) New hosts of Myrothecium spp. in Brazil and a preliminary in vitro assay of fungicides. Braz J Microbiol 41(1): 246-252.

9. Souza-Motta CM, Cavalcanti MAQ Fernandes MJS, Lima DMM, Coimbra JP, et al. (2003) Identification and characterization of filamentous fungi isolated from the sunflower (Helianthus annus L.) rhizosphere, according to their capacity to hydrolyseinuline. Braz. J. Microbiol 34(3): 273-280.

10. Costa I, Wanderley PM, Cavalcante MA, Fernandes MJ, Lima DMM (2006) Hyphomycetes from soil of an area affected by copper mining activities in the State of Bahia, Brazil. Braz. J. Microbiol. 37(3): 290-295.

11. Domsch KH, GamsW, AndersonT (2007) Compendium of soil fungi. $\left(2^{\text {nd }}\right.$ edn). IHW Verlag. Eching, Germany 672.

12. Ahrazem O, Gomez-Miranda AP, Bernabe M, Leal JA (2000) Heterogeneity of the genus Myrothecium as revealed by cell wall polysaccharides. Arch. Microbiol 173(4): 269-302.

13. Talukdar D,DantreRK (2014) Biochemical studies on Myrothecium roridum Tode. Ex. Fries causing leaf spot of Soyabean. Glob. J. Res. Ana 3(6): 7-9.

14. Kim DK, Lee SC, Han KS, Kim HK (2003) Detection of Myrothecium leaf spot, a new disease of watermelon. Plant Pathol. J 19(4): 200-202.

15. Khan SA, NazS, Mohy-Ud-DinG, Farooq S, Najeeb UllahM (2015) Fungicidal activity of aromatic medicinal plants against Myrothecium roridum Tode associated with Myrothecium leaf spot disease of Momordica charantia L. (Bitter gourd). Sci. Int. (Lahore) 27(3): 21692172.

16. Sheikh AW (1990) Seed-borne pathogens of vegetable crops grown in Pakistan (1984-1985). Summaries of Research Project 1967-1988. DGISP, Denmark.

17. Shakir AS, MirzaJH (1992) Seed-borne fungi of bottle gourd from Faisalabad and their control. Pak J Phytopathol 4: 54-57.

18. Ali S, A Wahid, Murtaza M, Nadeem A (1988) Myrothecium leaf spot of bitter gourd in Pakistan. Pak. J. Agric. Res. 9: 598-600.

19. Sultana N, Ghaffar A (2009) Pathogenesis and control of Myrothecium spp, The cause of leaf spot on bitter gourd (Momordica charantia Linn.). Pak J Bot 41(1): 429-433.

20. MacFaddin (1985) Media for isolation-cultivation-identificationmaintenance of medical bacteria, Vol.1. Williams \& Wilkins, Baltimore, Md 26(4): 240-240.

21. Fish WW, Bruton BD, Popham TW (2012) Cucurbit Host Range of Myrothecium roridum isolated from watermelon. Am J Plant Sci 3: 353-359.

22. SAS Institute (1990) SAS/STAT Users Guide version 6. SAS Institute, Cary, NC, USA.

23. Russel DF, Eisensmith SP (1983) MSTAT-C. Crop Soil Sci. Dept. Michigan State University, USA.

24. Leath KT, Kendall WA (1983) M. roridum and M. verrucaria Pathogenic to roots of Red Clover and Alfalfa. Plant Dis 67(10): 1154-1155.

25. McLean DM, Sleeth B (1961) Myrothecium rind rot of Cantaloupe. Plant Dis. Rpt 45: 728-729.

26. Khan SA, KamalM (1968) The fungi of south west Pakistan. Pakistan J Sci and Indus. Res 11: 61-80.

27. Bruton BD, Zitter TA, Hop-Kins DL, CET (1996) Crater Rot: Compendium of cucurbit diseases. The American Phytopathological Society, St. Paul Pp. 49-50.

28. Ponappa KM (1970) On the pathogenicity of Myrothecium roridumEichhorniacrassipes Isolate. Hyacinth Cont Jour 8(2): 18-20.

29. Gaikwad SJ (1988) Host range studies of Myrothecium roridum Tode ex. Fr. The causal organism of Myrothecium leaf spot disease of pearl millet. Punjabrao Krishi Vidyapeeth Research Journal 12: 162-163.

30. Meyer MC, Silva JC, Maia GL, Bueno CJ, Souza NL (2006) Myrothecium leaf spot of cotton caused by Myrothecium roridum. Summa Phytopathologica 32(4): 390-393.

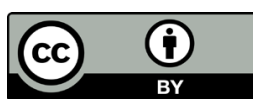

This work is licensed under Creative Commons Attribution 4.0 License DOI: 10.19080/JOJHA.2018.01.555577

\section{Your next submission with Juniper Publishers will reach you the below assets}

- Quality Editorial service

- Swift Peer Review

- Reprints availability

- E-prints Service

- Manuscript Podcast for convenient understanding

- Global attainment for your research

- Manuscript accessibility in different formats

( Pdf, E-pub, Full Text, Audio)

- Unceasing customer service

Track the below URL for one-step submission https://juniperpublishers.com/online-submission.php 